\title{
The Origins of Contemporary Moral Education and Political Ideology in Confucian-Marxist Hồ Chí Minh's Vietnam
}

Forkan $A L I^{*}$

\begin{abstract}
As an emerging East-Asian country, Vietnam has been influenced by the forces of communism, colonialism and predominantly Confucianism. Though Confucianism has an enduring operational history in Vietnam, Singapore, Korea, Japan, Hong Kong and Taiwan, after the nineteenth century it takes a different turn and plays an effective role in contemporary social, political and cultural milieus in this emerging part of the world. In the context of the genealogical ups and downs of Confucianism in East Asian countries like Vietnam, this critical analytical essay discusses Confucianism as trans-national phenomena and a certain way of thinking which has been transformed historically across generations and influenced moral educational and political ideologies of the peoples of Asia. Confucian values have strong practical implications with regard to Asian societies, politics, cultures, religions and education systems. In particular, this article attempts to demonstrate how Confucianism continues to function despite the influences of Marxism and European colonialism in Vietnam, and how it contributed to shaping the present-day country.
\end{abstract}

Keywords: contemporary Confucianism, Vietnamese Confucianism, Confucianism and East Asian Countries, transnational phenomena, political, moral and educational ideology

\section{Izvori sodobne moralne vzgoje in politične ideologije $v$ konfucijansko- -marksističnem Hošiminhovem Vietnamu}

\section{Izvleček}

Na Vietnam kot nastajajočo vzhodnoazijsko državo sta vplivala komunizem in kolonializem, v največji meri pa konfucianizem. Čeprav ima konfucianizem v Vietnamu, Singapurju, Koreji, na Japonskem, v Hong Kongu in Tajvanu dolgo zgodovino, je po devetnajstem stoletju prišlo do obrata, ki je odločilno vplival na sodobno družbo, politiko in kulturo $v$ tem delu sveta. $V$ okviru genealoških vzponov in padcev konfucianizma v vzhodnoazijskih državah, vključno z Vietnamom, članek obravnava konfucianizem kot transnacionalni pojav in specifičen način razmišljanja, ki se je skozi generacije

* Forkan ALI, PhD Candidate, School of Literature, Art and Media,

The University of Sydney, Australia.

Email address: forkanali.ali011@gmail.com

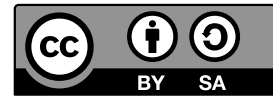


zgodovinsko spreminjal ter vplival na moralno vzgojo in politične ideologije azijskih narodov. Konfucijanske vrednote močno vplivajo na azijske družbe, njihove politike, kulture, religije in izobraževalne sisteme. Članek poskuša pokazati, kako konfucianizem kljub vplivom marksizma in evropskega kolonializma v Vietnamu še naprej bistveno vpliva na oblikovanje današnje države.

Ključne besede: sodobno konfucijanstvo, vietnamsko konfucijanstvo, konfucijanstvo in vzhodnoazijske države, transnacionalni pojavi, politična, moralna in izobraževalna ideologija

\section{Introduction-Inception of Confucianism in Vietnam}

Though it has had to compete with several dissimilar schools of thought, Confucianism $^{1}$ has never lost its appeal. Ideas derived from Confucius's philosophy ${ }^{2}$ are universal, modern and always relevant, and thus Confucianism is contemporary. Confucianism has influenced Asian culture, society and politics in a significant manner, and thus contributed to shaping global history. While Confucianism originated in China, its long-lasting cultural, historical and political developments and features have heavily influenced Asian intellectuals and spread across East Asian societies. Though there are some theoretical underpinnings regarding Confucianism's internal and external implications and features in countries like China, Japan and Korea (Lai 2018), in Vietnam it takes interesting turns before the nineteenth century and after, and dominated 20th-century socio-culture and political organization of Vietnam (Whitmore 1984).

Being the easternmost country in the Indochina basin, Vietnam shares borders with China, Laos, Cambodia and Thailand. The Vietnamese have strong affinities with Indonesian and Thai ethnic groups, but it was the Viet Tribes who established the Kingdom of Van Lang near the Red Delta Sea and in the northern part of the country during the seventh century BC (Buttinger 1972, 22; Slote and

1 Confucianism is designated as a school of thought, a philosophical movement, a religion, a set of principles and teachings on life (Cua 2013; Yao and Yao 2000). Confucianism derived from the Hundred School of Thought, a school of philosophical thought that arose in the 6th to 3rd centuries $\mathrm{BC}$ (usually understood as a period in which a hundred (diverse) schools of thought arose, not as a single school of thought lasting for a particular period). The philosophers of Spring Autumn Period (771 BC-476 BC), Confucius' (551 BC-479 BC) and Mencius' (385 BC-303 BC) teachings and concepts are popularly known as Ruism or Confucianism (usually Confucianism is broader than just the teachings of Confucius and Mencius).

2 The thoughts and teachings of Confucius, who has long been worshiped by the Chinese people as the leading sage and greatest Chinese philosopher, are called Confucianism (Cua 2013; Yao and Yao 2000). 
De Vos 1998, Chapter 2). The Kingdom of Van Lang was conquered by other tribes from North Vietnam and the Southern part of a Chinese province named Guangxi in late third century BC, and they created a new kingdom called Au Lac (Slote and De Vos 1998). Late in the second century BC Au Lac was invaded and named Nam Viet by the Qin general Trieu Da, a high-ranking officer from the Chinese dynasty during the second and third centuries BC. Nam Viet was again conquered during the Han dynasty in the early second century $\mathrm{BC}$ and ruled till 938 (AD) (Mok 2014). During this long period of military rule, Confucianism was introduced in Nam Viet.

The Chinese rulers generally did not impose their traditions, customs and cultures on the Vietnamese. They only controlled territorial issues related to the military and the allocation of administrative posts. It was the Han dynasty which divided Nam Viet into prefectures (jun) and then into districts (xian), and then the feudal lords were appointed as the chiefs of the prefects (ibid.). The organization of people and their lifestyles were highly influenced and managed by the Viet tribal lords and Viet tribes maintained their own cultures and traditions.

It was the Chinese officials, settlers and their families who followed and exercised Confucius principles in their way of life and moral teachings. Later, the Chinese administration adopted the policy of assimilation and spread Confucius' ideology among the Vietnamese people at the dawn of the Christian calendar, especially when prefects like Xi Guang and Ren Yan instituted Confucian principles in their moral teachings and marriage rituals. Moreover, the Viet people who adopted the Chinese customs received financial and social benefits within their districts (Slote and De Vos 1998). However, some prefects like To Dinh took strict measures to assimilate people to Confucius' teachings and faced fierce protests, especially by female leaders, as Viet tribes were a matriarchal society. Because of such protests, the Han government replaced the prefect chiefs with Chinese officials and instituted an official Chinese assimilation policy in Vietnam, and Confucian principles were also imposed on Viet society, particularly regarding family teachings, where women played a very crucial role (Wilson 1995).

\section{Early Transformation of Vietnamese Society and Confucianism}

With the transformation of social organization in Vietnam, Confucianism also transformed. In Viet tribes, women were the heads of families and therefore there were many occasions where women protested against the Chinese government, particularly in between the second to sixth centuries. After many unsuccessful attempts, the revolution was taken over by the males in the society, and since by 
then the traditional matriarchal Viet society was transformed into a patriarchal one (Mok 2014; Slote and De Vos 1998). Family teachings, family names, and customs were governed by the males, where Confucian principles already played a role. In the tenth century, Vietnam achieved independence from Chinese domination, but Confucianism remained embedded in Viet society and was exercised following the principles of male control. What is interesting is that Confucianism was not the dominant school of thought in Vietnam during this time. Traditional Viet customs and cultures were always maintained. Moreover, along with Confucianism, Chinese officials also instituted Buddhism and Taoism (ibid.).

Vietnamese Confucians scholars served the Chinese government in many parts of China, and were also followers of Buddhism. After the independence of Vietnam, these officials returned to Vietnam and were given important positions, although they were reluctant to engage in political affairs and instead pursued moral teachings (ibid.). They thus influenced Vietnamese moral, educational and legal affairs and also taught Buddhism and Confucianism to the educated government officials and spread the philosophy of Confucianism amongst a new generation.

Between the eleventh to thirteenth centuries, and especially during the Ly dynasty (1054-1072), the influence of Confucianism was increasing, and Buddhism was becoming less significant. Under the rule of the Emperors Ly Thanh Tong, Ly Nanh Tong and Ly Cao Tong, various initiatives were taken to institutionalize Confucian principles, and Confucius temples, Confucius examination systems, and educational policies were established. Though Buddhism attempted to be influential under Tran and Ly rule, Confucianism remained predominant within Vietnamese society (Slote and De Vos 1998). People felt more comfortable with traditional Confucian teachings and ways of life, where family ties are given high value.

The Confucian scholars were able to convince rulers like Tran Du Tong about the superstitions and limitations of Buddhism and Taoism, and encouraged them to adopt the Chinese institutional practice of Confucianism (Mok 2014). They not only rejected the mystical and superstitious features of Buddhism and Taoism, but also called for more vigorous moral educational and a better understanding of metaphysical principles. Among these scholars, Han $\mathrm{Yu}$ and $\mathrm{Li}$ Ao were famous for bringing something like Neo-Confucianism, which became prominent in the Song dynasty (960-1279) and Ming dynasty (1368-1644). Although Taoism and Buddhism influenced Confucianism during and after the Han dynasty, by rejecting their superstitious elements Neo-Confucianism could offer a more secular form of Confucianism (Blocker and Starling 2010, 64). Neo-Confucianism borrowed its framework from Taoism and its core philosophy can be seen as rational 
and humanistic: the whole universe can be known through reason, and it is possible to build harmonious relationship between the individual and the universe (Craig 1998, 552). However, unlike Buddhism and Taoism, Neo-Confucianism emphasized metaphysics as a method of generating a logical ethical philosophy, where Buddhists and Taoists used metaphysics as a tool for religious progress, enlightenment and morality (de Bary 1989, 94-5).

There were many ups and downs with social and political issues, but Confucianism continued to be one of the most influential ideologies among the Vietnamese. The people from Northern Vietnam, compared to those from Southern Vietnam, were more influenced by the practices of Confucian principles and there were some problems regarding this until the Nguyen Dynasty reunited the country and established a new order in the eighteenth century. During this time Confucianism received a new motivation. The rulers of the Nguyen dynasty (1802-1945) modelled Confucianism on the Chinese model, and followed the Chinese institutional and legal codes. For example, in the early nineteenth century the Emperors Gia Long and Minh Mang constructed their forms of government as per the Chinese system. In order to reinforce Confucian morality, Minh Mang instituted ten articles of moral conduct to be followed by the entire nation (Woodside 1971). Before the French arrived to establish their colony in Vietnam, the people experienced a very concentrated form of Confucianism in many aspects of their private and public lives. Though not completely, over hundreds of years of domination Chinese cultural, moral, political and social influence introduced to the Vietnamese people Confucian principles and ways of life, and for most of the time Confucianism also remained as a form of a state ideology (ibid.).

Near the end of the nineteenth century the French colonized Vietnam and started to reform the socio-political atmosphere of society. Therefore, Confucianism did not work as the state ideology anymore, but was still practiced through people's daily lives. Confucian philosophy continued to be the moral foundation for $\mathrm{Vi}$ etnamese people in many villages, where Confucian scholars worked as mentors in areas such as moral education, marriage and death (Marr 1980). During this period of Western influence, particularly in the early twentieth century, a new generation of Confucian scholars emerged who challenged the traditional way of practicing Confucianism and formed a club named the Self Reliance Pen Club (Tu Luc Van Doan). One of the major issues of Confucianism, as practiced traditionally, is the influence of parents as well as obedience to elders who dominate the young. Though they never denied the respect for and importance of parents, these young reformers called for more liberty and choice in their personal lives, especially in choosing their spouses (Marr 1980; Slote and De Vos 1998). From World War I to World War II, Confucianism went through a dramatic change, but 
the Vietnamese people never left the core values of Confucius teachings until a new ideology, Communism, was introduced (Cooke 1994).

\section{Introduction of Marxism in Vietnam}

After World War II, the global political and social phenomena impacted Vietnamese society, and eventually after the division of Vietnam in 1954 there were moves to form a new society based on Marxism. Studies show that the Vietnamese people who established the Indochinese Communist Party (ICP) in 1930 were introduced to Marxism through Lenin's "Theses on National and Colonial Questions":

They were much more attracted by the pragmatic response to colonial subjugation that Lenin's theses and Comintern affiliation provided by than by the theorems of dialectical materialism. As member of dissident elite of a colonized country steeped in a mythology of resistance to foreign rule, they could not help but focus on those aspects of doctrine which pointed out a road to national liberation and personal power. Flexibility and pragmatism in the choice of means have been hallmarks of Vietnamese communism ever since. (Turley 2019, 5-6)

However, to install a revolutionary ideology like Communism into the Vietnamese collective mind, the Communists needed to suppress the dominant Confucian principles and scholars who advocated them. ${ }^{3}$ The Communists first concentrated on the family ties that were based on Confucian principles and had been practiced over generations. During this period there was an historical process in which the Vietnamese fashioned responses out of their own past. The Communist Party first undertook this process in their "Vietnamese Communist views of nation's history and of the party's role ... and they have acknowledged local expectations and emphasized continuity ... and declared that nation and socialism are one" (ibid). Once they had introduced communism, the Communist leaders pulled the younger generation into their revolution and made them look again at their family relations by claiming that Confucianism was a feudal system which was dragging the progressive Vietnamese people backward (Huỳnh 1986). The Confucianists then started to feel that under the grip of communism they had no future in Vietnam. This atmosphere continued until the revolutionary leader, Hồ Chí Minh, came to power.

3 For more about the long history of Confucian ideology and the inception of Marxism in Vietnam see Nguyen Quoc Pham's "Marxism and Socialist Orientation in Vietnam" (2006, 205-6). 


\section{Hồ Chí Minh's Embrace of Confucianism and Marxism}

Hồ Chí Minh (1890-1969), also known as Nguyễn Tất Thành or Uncle Hồ, was a Vietnamese revolutionary who is often called a man of "cultural personality" (Brocheux 2007). This section of the essay briefly highlights Hồ Chí Minh's embrace of Confucian values and their influence on the version of communism he promoted. Hồ not only ended the rivalry between communism and Confucianism, but also transformed Confucian values into his nation's revolutionary zeal for independence. He considered Confucian moral virtues as indispensable for the Vietnamese people, and re-instituted those virtues necessary for the revolution and the revolutionary context of his country. In his book Let's Change Our Method of Work, written under a pen name XYZ in 1947, he showed how Confucius' idea of the nobleman truly can turn into a revolutionary one (Nam 2018).

Minh grew up in an environment where Confucian values were given high importance. Though Vietnamese society went through an extensive transformation during French colonialism, this was mostly limited to the cities. Villages were not completely free from colonial exploitation, but did not relinquish their insights regarding social relationships and organized communities (Lê 1989, 259-60; Duiker 2018). Minh passed his early life in this atmosphere, where he closely experienced the cultural practices of Vietnamese rural areas that he maintained throughout his life, even while he was abroad for a long time and exposed to Marxism. On one side he was learning and understanding the ideologies of Marx and Lenin, while on the other he was following Confucian values, including those of humaneness, knowledge, righteousness and integrity. What is important to note here is that the village where Minh grew up, named Kim Lien, was a significant place for Confucian studies and popularly known as the "civilized land and the place of Shi and Shu" (Lê 1989, 261). Shi and Shu refer to two works called Shijing (Book of Odes) and Shujing (Book of Historical Documents) by Confucius. This place became a centre for many Confucian scholars who influenced Minh's growing mind and become the backbone of his cultural and intellectual background. His family also contributed to this process of development, as his father Ngyen Sinh was a Confucian scholar. Moreover, before he left for the West, Minh actively studied Confucianism for ten years (ibid.).

While he was in the West, Minh always introduced himself as a Confucian admirer, and the values he learned never disappear during his long introduction to the modern West and to Marxism. Rather, he received new ideology (Marxism) and used it to help develop his own ideas (Son 2013, 39), as it helped him "objectively appraise his own raison d'etre in the new social and political circumstance" of his country (Lê 1989, 14). He not only integrated his knowledge of Confucian values 
and Marxist ideology in his political practice in Vietnam, but also promoted them explicitly through his writings and speeches. When later the Chinese Nationalists in Guangxi imprisoned him from 1924 to 1943, Minh wrote extensively in Chinese about his Confucian philosophy, reflecting his knowledge of intrinsic values regardless of physical constraint, which is similar to the understanding of ancient Chinese and Vietnamese scholars (ibid., 280).

Minh did not confine his knowledge within a certain boundary. Though there might be some similarities, Ho did not follow Confucianism like Neo-Confucians, nor did he take it as a politicized Imperial dogma. Instead, he understood "Confucianism as a tradition of Philosophy" (Son 2013, 40), and not a religion but a school of thought. Always considering Classical Confucianism as the basis of his knowledge, Minh saw the fundamental values of Confucianism as a universal form of knowledge which, for him, appeared to be continuously meaningful for modern Vietnam. The basis of this understanding became even stronger on two grounds, especially when he was introduced to Marxist ideology. Initially, he understood the essence of Marxist ideology for social harmony and considered Confucianism to offer directions for moral cultivation and appropriate inter-personal relations with an aim of establishing social harmony (ibid.).

Secondly, communism as a science of ethical experience and rules of conduct celebrates the idea of datong, "Great Unity". The idea of datong, which was introduced by Confucius and promoted by his disciples like Mencius, appeared to be a useful condition for appreciating Communist internationalism, and therefore to Minh Confucianism was compatible with communism (Lê 1989, 233-34). Minh applied both communism and Confucianism in his specific political vision. If Marx's ideas can be based on the history of philosophy of Europe, Minh revised them in reference to the history of philosophy of Asia. He considered the basis of Confucian tradition in East Asian history, specifically in China and Vietnam. This allowed him to find the relevance of classical Confucian values to review and reinforce Marxism in the contemporary context of Vietnam. Therefore, more dialogues could be initiated to examine the obvious relation between Confucian and Marxist institutions and principles.

\section{Marxist Hồ Chí Minh and Confucius Moral Virtues}

Soon after WWII, the people of Vietnam fought for their liberty, to free themselves from French and Japanese colonialism. Eventually, with the surrender of Japan at the end of WWII, Hồ was the leader of the League for the Independence of Vietnam (Viet Minh), and under his guidance in 1945 the League announced 
a new country, called the Democratic Republic of Vietnam (DVR). On 2 September 1945 in Hanoi, Hồ declared independence for Vietnam, including in his speech Jefferson's proclamation: "all men are created equal" (ibid., 133). Later in 1946, Hồ's DVR were involved in direct clashes with the French colonial powers that put all its strength into holding its colony in Vietnam and demanded the DVR forces surrender their arms. Hồ rejected the French demand and called for national resistance against colonial rule, and fought against the French army and a secret mission called Lea Campaign that was initiated to destroy DVR forces. This mission failed, and thus Hồ established the basis for a new philosophy—mixing Confucian and modernist values together (Brocheux 2007; Nam 2018).

In the book Let's Change Our Method of Work, Hồ has a chapter called "Revolutionary Virtues", where he presented a brief description of the moral values that a Party member or cadre should have in order to be a revolutionary person. Hồ mentioned five good virtues:

It is not difficult for a cadre to become a real revolutionary if he wants to. Everything depends on his heart-and-mind (lòng minh). If his sole interest is the Party, the country, and his compatriots, he will gradually become just and selfless (chi công vô tu 至公無私). As he has been just and selfless, his faults will progressively decrease, and his virtues described below will become increasingly apparent each day. In brief, the good virtues are five in all: humanity (仁), righteousness (義), knowledge (智), courage (勇), and integrity (廉). (Hồ in Nam 2018, 138)

The phrase "totally just and selfless" later became one of the basic moral values for a revolutionary as a member of the Vietnamese Communist Party, and these moral virtues are the same as the Confucius virtues needed to be a nobleman. Moreover, in the first chapter of the book, called "Classic of Loyalty", Hồ discusses what he means by loyalty. For him, loyalty is to be "totally just and fair", and also "being whole-hearted" (ibid.). Hồ's ideas regarding revolutionary virtues are central to being loyal to the country, the Party and the people, and also being able to distinguish right from the wrong.

\section{Hồ Chí Minh's Forms of Government and Confucianism}

Near the end of the twentieth century Hồ Chí Minh became the subject of scholarly attention in relation to Confucianism. Scholars divided into two sides: Hồ is a critic of Confucius, or Hồ is a person who practiced Confucianism all his life and applied many of classical Confucian principles in his forms of government 
(Nguyêñ 1974; Brocheux 2007; Son 2013, Nam 2018). Hồ's idea of good government is an amalgamation of institutional and legal management with moral virtues. The French colonialists made every attempt to break the cultural heritage of the Vietnamese people, while the Communists tried to suppress the Confucian zeal present amongst the people in the towns and villages. As a leader, Hồ Chí Minh, in this case, was quite pragmatic and did not make the same mistakes. Rather he combined some classical Confucian principles into his vision of government and institutions.

Vietnamese urban society during Hồ Chí Minh's time was heavily influenced by French colonialism, and Confucianism went through a radical transformation. But people from the rural areas were practicing Confucian ideology in their daily lives. As mentioned before, Hồ grew up in this rural environment and absorbed Confucianism in his young mind, as reflected later in his life, as the values embedded in Vietnamese society for centuries shaped his adult personality (Brocheux 2007). Hồ was introduced to Confucius studies and philosophy by scholars who frequently gathered to discuss the teachings of Confucian virtues. This environment enlightened Hồ culturally and intellectually. Being exposed to the traditional philosophical teachings of Confucianism from works like the Analects of Confucius, which was achieved in its ultimate form during the Han dynasty, and the Works of Mencius, Hồ was not influenced by the dialects that politicized the doctrines of Confucian principles. Therefore, he supported the fundamental virtues and teaching of Confucianism, which he incorporated for the making of modern Vietnam. In a discussion with the Russian literary scholar Osip Mandelstam, held in 1923, Hồ stated:

I was born into a Vietnamese Confucian family. ... The youth from those families often studied Confucianism. Comrade, you must know that Confucianism is not a religion but a science of moral experience and conduct. Based on this foundation, one puts forward the notion of the "Great Unity". (Nam 2018, 135)

As we can see, for Hồ Confucianism was not a religion but a school of philosophical thought which accommodates principles and teachings of moral virtues, as well as the way of creating unity and social cohesion. He also revised Marxism in relation to its historical basis, incorporating not only European history but also that of Asia, where he finds Confucian customs with a basis on East Asian history, particularly in respect to China and Vietnam. In this way of consolidating East Asian history, Hồ always considered the people as the core of power. He believed there is nothing more powerful than the people. Therefore, they should be at the centre of any government (ibid.): 
In the Communist Review of the Third International in May 1921, Nguyen Ài Quóc introduced to the West the Confucian concept of minben by restating Mencius' famous restatement: " most important element in a nation, the spirits of the land, and grain are the next; the sovereign is the lightest". With that Mencian inspiration, one year later Nguyen Ài Quóc chastised Emperor Khài Dinh during the imperial visit to the Marseille Exposition in the article entitled "The Laments of Trung Trac" published in the L'Humanite on 1 June 1922. (Son 2013, 43)

He considered the people as water and the government as fish in it. Hồ advocated the Confucian concept of minben, where the people are considered to the basis of everything. The concept of minben was practiced in ancient Vietnam, when people considered that "a legitimate government must be responsible for the happiness of the people" (Son 2013, 43). The Confucian concept of minben is in the centre of Hồ's vision of government. He respected democracy but his vision is more about "for the people" rather than "of the people". In an article in 1949 on "Public Relations", he states that: "our country is a democratic country. All benefit is for the people. All power is of the people. Renovation and construction are the business of the people" (ibid., 44). For him, independence is meaningless without the absolute freedom and happiness of the people. For this to happen, Hồ advocated the practice of moral virtue not only in personal life, but also in the government. Self-cultivation of individual morality should make a political man (Waley 2012). As in Confucius' Great Learning (Daxue), which is one of the four texts of Confucian learning, ${ }^{5}$ good government is the product of the moral cultivation of the political men (Watson 2007). Similar ideas about the learning of good government and the morals of the rulers is also present in Spring and Autumn Annals, another of the four texts of Confucius (Miller 2015; Milburm 2016). Hồ also takes this positive view of government, and re-educates the people of his government with these moral virtues in which the external arrangements of the institutions are less important than the internal moral arrangements of the people in the institutions. To re-establish the self-cultivation of the morality of the members of the new republic for the people, Hồ advocated following the essential Confucian values.

$4 \quad$ For more about Mencius' statements see James Legge (1960, 483).

5 Technically, it is one of the Four Books canonized in Song-Ming Neo-Confucianism (and not the earlier Confucian tradition), to form the core subject matter of the Imperial examination system. 


\section{Confucian Values and Moral Education in Contemporary East Asia}

The legacy of Confucian thought is active in East Asian countries. Confucian influences on East Asian socio-cultural and economic modernization and nation-building are especially noteworthy. Countries like Japan consciously employed traditional Confucian ideology for nation-building and industrialization. The Japanese also strongly maintain religious teachings in relation to the Analects of Confucius (Kizo 2018). Therefore, Confucianism turns out to be a pan-Asian phenomenon that can accommodate inter-related cultures. In the introduction to their edited volume, Roger Ames and Peter Hershock write:

Over time, this intergenerational embodiment and transmission of an aggregating Confucian culture spread throughout the East Asian world of Korea, Japan, and Vietnam to become a pan-Asian phenomenon that over the centuries has shaped and been shaped by this family of distinctive and yet inter-related cultures. And, the evidence today is that many in Asia feel that Confucian culture can make valuable contributions to the articulation of a new world cultural order. Enormous resources are being invested in China and other Asian cultural spheres to renew traditional Confucian learning as a repository of values and conceptual resources that can be drawn upon to shape their responses to contemporary dynamics. (Ames and Hershock 2018, 5)

Taking Confucianism as a long-lasting, cross-cultural set of values, and seeing the efficacy of (some) Confucian teachings and practices, countries like Japan, Hong Kong, Taiwan, South Korea and Singapore were able to achieve both economic and social development. These countries have re-studied and adapted the traditional values to make them suitable to serve their purposes to build new nations. Japan, particularly during the Meiji Reformation and WWII, has used Confucian ideas in its educational curriculum and official documents with a view to combining industrialization with the traditional Confucian Japanese devotion to the family and customs (Du 1996). In much the same way, the Singaporean government has used Confucian ideas as a way of bringing modernization and political power, in which the importance of family harmony and admiration for authority were tactically maintained to achieve consistent social and economic stability (ibid.). Using the family as the basic unit of the social structure, like Japan and Singapore, Taiwan also connected Confucian ideas to developmental strategies and political locality, and proved that maintaining long-term traditional family structures brings economic and political success. Ethnic Chinese people in Thailand, Malaysia and Singapore have also sustained this ideological ground. 
The commitment to Confucian values and family ties has been strengthened in order for them to be able to survive in challenging atmospheres like Hong Kong and South Korea. Along with other East Asian countries, these two societies also reinterpreted traditional Confucian ideas and adapted them their modern economic and social systems. From education to personal lifestyles, Confucianism has evolved as a new way of looking at the political and social organization and arrangement of institutions (Wang 2008). Perhaps, it is the Confucius zeal that leads such countries to combine a democratic educational system with traditional values, and allows them to adjust to new political and economic difficulties.

\section{Ideological Dynamics in the Contemporary Vietnamese Educational System}

From the above discussion, it is evident that the people of Vietnam have experienced the dissimilar forms of social organization and principles of both Confucianism and communism. The people have also experienced different religions, including Buddhism, Taoism and Catholicism. Therefore, the educational principles in contemporary Vietnam have different forms of ideological understanding. Moral education is consolidated in the formal education system, which is based on personal moral principles, political and citizenship teachings. In all of these educational processes not only are Marxist ideology and the thoughts of Hồ Chí Minh present, but also Confucian philosophy, although mostly at the primary level. Most of these ideologies come under a broad term called moral education-traditional Confucian moral education, which mostly developed through both an informal method of education, like family or religious education, as well as a formal method like Marxist socialist moral education through the national curriculum (Nguyen 2004). For example, according to the Ministry of Education and Training, primary level students are taught about two different system of morality in Vietnamese society, that is traditional and socialist morality. ${ }^{6}$ At the secondary level there is no subject like morality taught, but instead civics, where Marxist-Leninist philosophy is predominant. In 2018 the Ministry of Education and Training implemented a new national curriculum where morality and civics were challenged, although they remain in the system (Viet Nam News 2018). However, how moral education is objectively arranged within the emerging and changing Vietnamese society is still a matter of contest, especially since the society has experienced a long history with the values of Confucianism, Buddhism and communism.

$6 \quad$ See more at the Ministry of Education and Training (Thai 2006). 
The formal and informal educational journey for the people of Vietnam has gone through different stages, which are directly or indirectly related to national socio-cultural and political history. As mentioned above, Vietnam was under Chinese domination for about a millennium, particularly from the first century $\mathrm{BC}$ to the tenth century AD. Therefore, the earliest stage of the traditional Vietnamese educational system has a Chinese cultural influence. The intellectual and cultural organization of Vietnamese society was heavily influenced by Taoism, Buddhism and most importantly Confucianism. Therefore, the initial stage of the educational system was grounded on the principles and teachings of Confucian philosophies, the self-cultivation of morality, social harmony and political virtues. The next stage of the educational system, which was during the time of nineteenth and twentieth centuries was influenced by French colonial policy which was administered through Western Catholic missionaries (Thanh 2010). Though this Catholic, Western form of educational management influenced the Vietnamese language and culture, the traditional Vietnamese cultural characteristics and Confucian educational zeal continued to be a significant way of learning about morality and political ideology. In the twentieth century the educational system experienced a new turn, especially under the Democratic Republic of Vietnam, when the whole country was fighting for independence from Japanese and then French occupation (Nguyen 2004).

After the separation of the country into two separate parts, North and South Vietnam, the educational policy was also separated into two policies. The socialist model of education was implemented in North Vietnam, and a Westernized in South Vietnam, under French colonial rule. With the unification of the country the educational system was centralized under the Socialist Republic of Vietnam. With the economic reforms that began in 1986, the Đổi Mói (revolution) was implemented to serve the country's developmental needs, and the educational system changed into a socialist-oriented market economy (ibid.). Đổi Mói brought a radical change in the social, cultural and economic sectors of Vietnam, one that required huge public participation from all sphere of life. Therefore, the educational system was formally reorganized into five stages: pre-school, primary, secondary, higher and postgraduate education. Moral education was incorporated as one of the fundamental subjects in every stage of formal education.

\section{Forms of Moral-Political Education in Vietnam}

The Educational Law of 1998 formally adopted moral education in the curriculum at every stage of national learning. In this moral educational curriculum, 
issues like socialism, loyalty, good citizenship, cultivation of virtues, the natural environment, understanding foreign countries, inter-personal relations, appreciation of soldiers and national defenders, and nationality are included but mixed in an illogic fashion, which not only hints at the Marxist-Confucianist way of teaching, but also incorporates moral and political education. From pre-school to postgraduate studies, the aim is to create the next generation of fully developed Vietnamese citizens, but knowledge of politics and moral virtues remains inadequate (Doan 2005), and little interest in either politics or morality are observed by researchers (ibid.). Though the educational system of Vietnam never clarifies what it means by moral education (which often seems moral-political education), political education is highly emphasized in the forms of moral education where not only Marxist-Leninist political objectives are highlighted, but also some Confucianist traditional teachings are carried out.

Vietnam is modernizing and the sense of materiality amongst people is increasing. Due to social media and the growth of technology, Western notions of lifestyle are having an ever greater impact. Moreover, scholars claim that traditional social values seem to be fading away, as there are no definite moral educational aims as in the earlier stage of the educational system. The morality of a person and character building are less emphasized in the vague forms of moral-political education that now exist. Traditional Vietnamese moral education and virtues, which respect harmony and care, are disappearing in contemporary society (Nguyen 2004), with younger people preferring personal benefits over social and communal ones.

There are two forms of moral education prevailing in the Vietnamese educational system: traditional morality which has its roots in Confucian philosophy, and socialist morality which is based on Marxist-Leninist philosophy (Huong 2004). Confucianism advocates human relations, the happiness of people, personal moral cultivation, social order, humaneness, integrity and political virtues. Moreover, Confucian ideology emphasizes respect for elders, obedience to parents, and dedication to the development of the community. Though Confucian values, like the superiority of elders and men over subjects, juniors and women, have seen some revisions in contemporary Vietnam, due to the sense of freedom and personal choice that have come into play, younger generations also seek social harmony and happiness along with economic growth and career development. Yet these young people also have a clear understanding that without family harmony and respect there would be an imbalance in life, which would result in dissatisfaction. Though religious education is not officially included in the educational system of Vietnam, moral values and spiritual lessons are taught through families and religious institutions. Scholars claim that traditional Confucian values are more 
emphasized and learned through families than schools, as family education had worked as the dominant form of learning for a child since the very early in Vietnam. There are, however, instances where family relations and teaching are less emphasized, especially for the children of nuclear families and in cities, where maintaining traditional values is difficult.

The socialist educational system came into effect with the inception of communism in Vietnam, and continued to be one of the major forces of moral education (Wang and Namh 2019). Socialist moral education puts importance on socialist principles and respect for the workers, and highlights individual and collective duties towards the state, where the accomplishment of socialism is the prime concern. Unlike Confucian values, socialist values are exercised through institutions and formal education, which is mandatory. This obligation sometimes allows the younger generation to think of personal choices and perspectives, where career growth and economic stability have come to play a crucial role. In socialist values achievement is collective, which is contrasted with the market economy that emphasizes individual choice and satisfaction.

\section{Conclusion-Contemporary Confucianism and Contemporary Vietnam}

Confucianism is rational, contemporary and relevant to present-day social, political and moral studies. Ideologies like communism, Catholicism and European colonialism looks at Confucian values as something outdated and irrational. Confucian ideas emphasize affirmative thinking in relation to established norms and values, and connected with institutional arrangements. However, Confucianism is also critical, since many scholars argue for an interpretation of Confucianism that is opposed to Western philosophies and moralities that place "rationality" in the central role. ${ }^{7}$ For example, in the Analects, in the discussion regarding benevolence (ren) which indicates cultivating self through helping others, cultivating themselves through learning (хие), Confucius emphasizes:

To love benevolence without loving learning is liable to lead to foolishness (and that) learn widely and be steadfast in your purpose, inquire earnestly and reflect on what is at hand and there is no need for you to look for benevolence elsewhere. (Confucius 1979, "Benevolence" IV)

7 Being influenced by Neo-Confucianism, New Confucianists in contemporary times take a neo-conservative approach to Confucianism and use traditional Confucian ideas like social and political harmony for a comparative study with Western ideas like rationalism and humanism (Makeham 2003). 
Confucius often engages in critical discussions, his way of learning (xue) requires involvement in critical conversation that often looks for suggestions from others and motivates criticism: "words to gentle advice" (ibid.).

The importance of Confucian thought today has been demonstrated by the employment and reinvention of Confucian ideas in relation to current socio-economic and political developments. East Asian countries have been maintaining the Confucian philosophical ideology in their collective and personal life, and have now institutionalized Confucian ideas in their national interest and to encourage social empathy (Jang 2019). In these societies, the teaching of Confucius is exercised through informal institutions like family, as well as formal schooling through the national educational curriculum.

From the second century to present-day Vietnam, Confucian values and traditions are maintained through various religious, institutional and personal arrangements. Like other developing societies, Vietnam is also facing new challenges with regard to reaping the benefits of industrialization and political stability. At this particular moment, the national educational system requires a holistic transformation to meet the new challenges. Moreover, with the growing tensions of social and personal problems, like various abuses, divorces, corruption, addiction, and moral degradation, people in Vietnam are rethinking the foundation of the formal educational system. People are also concerned about declining traditional values, virtues and harmony in social relations. There is a growing demand for the reconstruction of a moral educational system and clearer moral teaching in order to help the development of the Vietnamese people, and Confucian values and teachings can play a vital role in this.

\section{References}

Ames, Roger, and Peter D. Hershock, ed. 2018. "Introduction." In Confucianisms for a Changing World Cultural Order, 1-6. Honolulu: University of Hawai'i Press.

Blocker, Gene H., and Christopher L. Starling. 2010. Japanese Philosophy. Albany: State University of New York Press.

Brocheux, Pierre. 2007. Ho Chi Minh: A Biography. Cambridge, UK: Cambridge University Press.

Buttinger, Joseph. 1972. A Dragon Defiant: A Short History of Vietnam. New York: Praeger.

Confucius. 1979. The Analects. Translated by D. C. Lau. UK: Penguin Books Limited. 
Cooke, Nola. 1994. "Nineteenth-Century Vietnamese Officialization in Historical Perspective: Evidence from the Palace Examinations (1463-1883)." Journal of Southeast Asian Studies 25 (2): 270-312.

Cua, Antonio S., ed. 2013. Encyclopedia of Chinese Philosophy. London: Routledge.

Chen, Lai. 2018. "Historical and Cultural Features of Confucianism in East Asia." In Confucianisms for a Changing World Cultural Order, edited by Roger Ames, and Peter D. Hershock, 102-11. Honolulu: University of Hawai'i Press.

Craig, Edward. 1998. Routledge Encyclopedia of Philosophy, vol. 7. London, New York: Routledge.

de Bary, William Theodore. 1989. The Message of the Mind in Neo-Confucianism. Columbia: Columbia University Press.

Doan, Dung Hue. 2005. "Moral Education or Political Education in the Vietnamese Educational System?" Journal of Moral Education 34 (4): 451-63.

Duiker, William J. 2018. The Communist Road to Power in Vietnam. London: Routledge.

Du, Weiming, ed. 1996. Confucian Traditions in East Asian Modernity: Moral Education and Economic Culture in Japan and the Four Mini-Dragons. Cambridge: Harvard University Press.

Huong, Pham Lan, and Gerald W. Fry. 2004. "Education and Economic, Political, and Social Change in Vietnam." Educational Research for Policy and Practice 3 (3): 199-222.

Huỳnh, Kim Khánh. 1986. Vietnamese Communism, 1925-1945. Ithaca: Cornell University Press.

Jang, Wonho. 2019. "Identification, Confucianism, and Intersubjectivity: Issues Related with Social Empathy in East Asia." Journal of Asian Sociology 48 (1): 43-52.

Kelley, Liam C. 2006. "Confucianism in Vietnam: A State of the Field Essay." Journal of Vietnamese Studies 1 (1-2): 314-70.

Kizo, Ogura. 2018. "Animism and Spiritualism: The Two Origins of Life in Confucianism." In Confucianisms for a Changing World Cultural Order, edited by Roger Ames, and Peter D. Hershock, 112-27. Honolulu: University of Hawai'i Press.

Lê, John Vān Hóa. 1989. “Cultural Foundation of Ho Chi Minh's Revolutionary Ideology." PhD diss., Northwestern University.

Legge, James. 1960. The Chinese Classics, with Translations, Critical and Exegetical Notes, Prolegomena and Copious Indexes, vol. II: The Works of Mencius. Hong Kong: Hong Kong University Press. 
Makeham, John. 2003. New Confucianism: A Critical Examination. New York: Palgrave Macmillan.

Marr, David G. 1980. Vietnamese Anticolonialism, 1885-1925. California: University of California Press.

Milburn, Olivia. 2016. The Spring and Autumn Annals of Master Yan. Netherlands: Brill.

Miller, Harry, ed. 2015. The Gongyang Commentary on The Spring and Autumn Annals: A Full Translation. Berlin: Springer.

Mok, Mei Feng. 2014. "The Story of Việt Nam: From Prehistory to the Present by Shelton Woods." Sojourn: Journal of Social Issues in Southeast Asia 29 (3): 776-77.

Nam, Nguyem. 2018. "The Noble Person and the Revolutionary: Living with Confucian Values in Contemporary Vietnam." In Confucianisms for a Changing World Cultural Order, edited by Roger Ames, and Peter D. Hershock, 128-62. Hawai: University of Hawai'i Press.

Nguyêñ, Khăć Viện. 1974. Tradition and Revolution in Vietnam. Ho Chi Minh City: Indochina Resource Center.

Nguyen, Phuong An. 2004. "Pursuing Success in Present-day Vietnam: Young Graduates in Hanoi." In Rethinking Vietnam, edited by Duncan McCargo, 165-76. London, New York: Routledge.

Pham, Nguyen Quoc. 2006. "Marxism and Socialist Orientation in Vietnam." Nature, Society, and Thought 19 (2): 201-6.

Slote, Walter H., and George A. De Vos. 1998. Confucianism and the Family: A Study of Indo-Tibetan Scholasticism. Albany: State University of New York Press.

Son, Bui Ngoc. 2013. “The Confucian Foundation of Hồ Chí Minh's Vision of Government." Journal of Oriental Studies 46: 35-59.

Thai, Trinh Quoc. 2006. "Vietnam Primary Education." Ministry of Education and Training. Accessed December 7, 2019. https://web.archive.org/ web/20120326105206/http://en.moet.gov.vn/?page=6.10\&view $=4401$.

Thanh, Pham Thi Hong. 2010. "Implementing a Student-Centered Learning Approach at Vietnamese Higher Education Institutions: Barriers under." Journal of Futures Studies 15 (1): 21-38.

Turley, William S. 2019. Vietnamese Communism in Comparative Perspective. Abingdon: Taylor \& Francis.

Viet Nam News. 2018. "New General Educational Curriculum Unveiled." Viet Nam News, December 28, 2018. https://vietnamnews.vn/society/482917/ new-general-educational-curriculum-unveiled.html.

Waley, Arthur. 2012. The Analects of Confucius. London: Routledge. 
Wang, Zhengxu. 2008. Democratization in Confucian East Asia: Citizen Politics in China, Japan, Singapore, South Korea, Taiwan, and Vietnam. New York: Cambria Press.

Wang, Jin, and Keebom Nahm. 2019. "From Confucianism to Communism and Back: Understanding the Cultural Roots of Chinese Politics." Journal of Asian Sociology 48 (1): 91-114.

Watson, Burton. 2007. The Analects of Confucius. Columbia: Columbia University Press.

Whitmore, John K. 1984. "Social Organization and Confucian Thought in Vietnam." Journal of Southeast Asian Studies 15 (2): 296-306.

Wilson, Thomas A. 1995. Genealogy of the Way: The Construction and Uses of the Confucian Tradition in Late Imperial China. California: Stanford University Press.

Woodside, Alexander. 1971. Vietnam and the Chinese Model: A Comparative Study of Nguyễn and Ching Civil Government in the First Half of the Nineteenth Century. Cambridge: Harvard University Press.

Yao, Xinzhong, and Hsin-chung Yao. 2000. An Introduction to Confucianism. Cambridge: Cambridge University Press. 